\title{
A Comparative Study on Social Media Use and Public Participation in Korea and the United States: Does Social Media Matter?
}

\author{
Eunyi Kim*
}

\begin{abstract}
This study examines how the use of different types of social media, such as Facebook and Twitter, affects public participation, drawing on the theory of motivation, which addresses the effect of internal and external political efficacy as well as the perceived political importance of social media. The study also investigates the interaction effect between social media use and perceived the political importance of social media on public participation. Employing a comparative perspective on an issue that has not been well studied, the study further seeks to discover potential variations in the impacts of different social media on public participation in the United States and Korea, both of which held presidential elections at the end of 2012. This study conducted hierarchical multiple regression analyses using data collected from college students in the United States and Korea. It shows the positive impact of social media use and its interaction effect with the perceived political importance of social media on the offline and online public participation of youth. The political motivational factor is found to be critical to driving public participation. This study also shows that the impact of Facebook use is more influential than Twitter use on public participation in the United States, whereas the opposite pattern is observed in Korea.
\end{abstract}

Keywords: social media, public participation, political efficacy, motivation

"If the presidential campaigns of 2008 were dipping a toe into social media like Facebook and Twitter, their 2012 versions are well into the deep end." (Wortham, 2012a)

* Eunyi Kim is a professor in the Department of Journalism and Mass Communication at Incheon National University. E-mail: eykim@inu.ac.kr.

Manuscript received February 23, 2015; out for review March 17, 2015; review completed March 27, 2015; accepted March 30, 2015.

The Korean Journal of Policy Studies, Vol. 30, No. 1 (2015), pp. 207-230.

(C) 2015 by the GSPA, Seoul National University 


\section{INTRODUCTION}

Do social media facilitate public participation? In particular, do young people, who are increasingly involved in social media, change their political behaviors as they become more connected and interactive via different social media? Is there any difference in the impact of social media on public participation among different social media or among countries? These questions have not been well studied even though they are an extension of a long-standing research interest in the nature of public participation by young people, who tend to be less interested in politics than older generations (Bakker \& de Vreese, 2011; Mindich, 2005; Putnam, 2000). In fact, there is lack of comparative studies that examine similarities and differences in the impact of social media on public participation among different social media services and in different political contexts. Previous studies have tended to investigate the impact of social media on public participation by focusing on either a single social medium or a single country (Choi \& Park, 2014; Kim \& Park, 2012; Woo \& Kim, 2009). Some studies have also examined the impact of social media in general without distinguishing among the potential differences associated with different forms of social media (Gil de Zúñiga, Jung, \& Valenzuela, 2012; Kim \& Park, 2012; Lee , Choi, Kim, et al., 2014; Park, Kee, \& Valenzuela, 2009; Tumasjan, Sprenger, Sandner, et al., 2010; Vitak, Zube, Smock, et al., 2011; Westling, 2007). This study attempts to make an empirical contribution to the literature by taking a comparative perspective, examining how the use of different types of social media, particularly Facebook and Twitter, affects the public participation of the young generation in two different political contexts, namely, the United States and Korea. The two countries are similar not only in that their populations are technologically savvy but also in that social media played an important role in the presidential elections of both countries in 2012.

Young people have shown increasing interest in social media and have become more connected and interactive on the Web. A 2010 study by the Pew Research Center indicates that $66 \%$ of Internet users identify as social media users, with approximately $86 \%$ of online young adults between the ages 18 to 29 saying they use social media. Due to the explosion in the popularity of social media, politicians are increasingly interested in using social media in their political campaigns. In the 2012 presidential election, for example, candidates extensively used social media to disseminate campaign information and mobilize volunteers and financial resources. According to a major daily newspaper, the Obama campaign more actively used social media than the Romney campaign; Obama's Twitter account attracted more than 20 million followers, and his Facebook page acquired approximately 30 million "likes," while Romney drew 1.2 million Twitter followers and 8 million Facebook "likes" (Wortham, 2012b). 
Responding to increasingly relevant but understudied research questions, this study examines how the use of different types of social media, in particular Facebook and Twitter, affects public participation among young people and investigates what the differences are between the United States and Korea in this regard. The study also examines the interaction effect of the perceived political importance of social media and the use of different types of social media on public participation. To address these research questions, an exploratory statistical analysis was performed using data collected from college students in the United States and Korea immediately prior to the presidential elections in late 2012.

\section{Social Media Explosion in the United States and Korea}

With the proliferation of Web 2.0 technologies, such as mashups, tagging, and Really Simple Syndication (RSS), since the mid-2000s, social media (e.g., Facebook, Twitter, YouTube, Tumblr, Instagram, and Flickr) have become one of the most rapidly growing online communication channels. ${ }^{1}$ Through social media, particularly Facebook and Twitter, young people are more engaged and connected than ever before. Social media first appeared in the early 2000s and began to spread dramatically in the midand late 2000s (Facebook in 2004 and Twitter in 2006). For example, the number of active Facebook users was only 1 million at the end of 2004, but it had increased to 150 million by January 2009 and soared to approximately 1 billion in September 2012. Pervasive social media use has directly and indirectly changed the ways in which individuals communicate and share information each other. In particular, the characteristic connectivity and interactivity of social media strengthen individuals' online social connectedness and may also affect heir offline civic and political engagement. These qualities also lead to higher social demands for openness, interactivity, participation, and information sharing among individuals, and satisfying these demands may lead individuals to become involved in politics.

Facebook has become the dominant social media site in both the United States and Korea. Data from Statistics Brain suggest that there were approximately 1.3 billion monthly active Facebook users as of January 2014. ${ }^{2}$ A global map of social media use reveals that social networks such as Facebook have spread across the world, excluding

1. Mashups are Web applications that are often used to collect and integrate relevant information for particular purposes; this technology is considered by many to be the Web 2.0 tool with the highest utility. RSS technology enables simultaneous updates of relevant subscriber information.

2. http://www.statisticbrain.com/facebook-statisti cs. 
several places such as China, where censorship laws officially ban Facebook (Arno, 2012). As Christina Arno has noted (2012), a compelling reason for Facebook's predominance among social media networks is that it features "globally local" communications, allowing people to create a presence "locally" in their chosen language and then communicate that presence "globally." As of the end of 2012, there were about 163 million Facebook members in the United States and about 8.2 million users in Korea (www.checkFacebook.com).

Twitter is likewise rapidly expanding and had reached 645 million registered active users as of January 2014. ${ }^{3}$ Particularly because of its unique format of a 140-character limit and its openness, Tweets from key political figures often attract many followers, and their messages are often retweeted or covered by traditional media. By the end of 2012, there were approximately 140 million U.S. users and approximately 7 million Korean users.

Political candidates and parties actively seek ways to take advantage of social media to gain support or set agendas. President Obama — who has more than 25 million Twitter followers, the most in the world - actively used Twitter during his presidential campaign to deliver short political messages to the public. His Twitter followers often retweeted these messages, making them visible to other site users. Politicians also often strategically use Facebook to reach out to constituents, especially young people.

There are several other locally active social media sites, such as vKontakte and Odnoklassniki in Russia, Mixi in Japan, and Zing in northern Europe.

Table 1. Comparison of Social Media Use in the United States and Korea (2012)

\begin{tabular}{c|c|c|c}
\hline Social Media & World & United States & Korea \\
\hline Facebook & 964 million & 163 million & 8.3 million \\
\hline Twitter & 500 million & 140 million & 7 million \\
\hline population & 7 billion & 316 million & 48 million \\
\hline
\end{tabular}

Sources: checkFacebook.com and techcrunch.com (November 2012)

\section{Public Participation Challenges in the Internet Age}

Although the core of democracy is citizens' political participation, there has been a decline in voting and political activities, and trust in political systems has been gradually decreasing. In particular, a sharp decline in public participation decline people in their twenties and thirties has been recognized as a widespread international phenomenon

3. http://www.statisticbrain.com/twitter-statistics. 
and major political concern in recent years, and researchers have attempted to determine which factors have contributed the most to this decline. Scholars have suggested possible remedies and highlight the role of new media in boosting public participation, some arguing that new communication technology may be able to remedy the problem of low participation problem (Castells, 2009; Metzgar \& Maruggi, 2009; Tolbert \& McNeal, 2003). Some research, however, has shown that Internet use may reduce face-to-face communication and engagement levels in civic affairs; as more time is spent in front of computer screens, less time is spent engaging in civic life (Cummings, Butler, and Kraut, 2002; Putnam, 2000). Based on an ethnographic study, Natalie Fenton and Veronica Barassi (2011) offered a cautious view, arguing that "the logic of selfcentered participation promoted by social media can represent a threat for political groups rather than an opportunity" (p. 183).

Owing to its complex and diverse nature, many researchers have eschewed narrow definitions of public participation. For example, Sidney Verba et al. (1995) define public political participation as any "activity that is intended to or has the consequence of affecting either directly or indirectly government action" (p. 9), such as elections or public policy making (Conway, 2000; Oh \& Park, 2014). Scholars have also proposed different public participation types based on, for example, on the degree of activity (i.e., active participation versus passive participation/political communication) and the types of media involved (i.e., offline participation versus online participation). Online public participation, for example, is likely to be passive because much of it constitutes information-based political communication rather than actual political action. Acknowledging the difference between communication and action, Lindsay Hoffman has defined online public participation as "an information-rich activity that utilizes new media technology and is intended to affect, either directly or indirectly, policy-makers, candidates, or public officials" (2012, p. 220). In addition, some scholars have investigated whether one public participation type affects other types. For example, Mark E. Kann et al. (2007) argue that online public participation affects traditional offline public participation, while Davide Calenda and Albert Meijer (2009) offer an opposing perspective, arguing that Internet use does not lead to changes in public participation patterns but simply reinforces old patterns. 


\section{THEORETICAL BACKGROUND}

\section{Theoretical Discussion of the Impact of Social Media Use on Public Participation}

Previous research on the impact of new media on public participation has identified two contrasting perspectives: the mobilization perspective and the reinforcement perspective (Kraut, Lundmark, Patterson, et al., 1998; Nie, 2001; Putnam, 2000; Shah, Kwak, \& Holbert, 2001). The former argues that new media, including social media, enhance the public participation of traditionally underrepresented populations by offering new channels for communication and involvement (Foot and Schneider, 2006); the latter asserts that new media do not necessarily contribute to political inclusion but may instead reinforce traditional modes of public participation (Cummings, Butler, \& Kraut, 2002; Delli Carpini \& Keeter, 2003). Despite the immense growth in social media use among Internet users and politicians, it remains unclear how different social media influence young people's behaviors with respect to public participation (Andolina, Jenkins, Faison \& Flanagan, 2001; Michelsen, Zaff, \& Hair, 2002; Wellman, Hasse, Witte, et al., 2001). Hun Myoung Park and James Perry (2008) have identified three perspectives on the impact of the Internet on political (public) participation: optimistic (the mobilization perspective), pessimistic (the reinforcement perspective) and skeptical (the normalization perspective).

Table 2. Three Different Perspectives on the Impact of New Media on Public Participation

\begin{tabular}{l|l|l}
\hline & \multicolumn{1}{|c}{ Key Arguments } & \multicolumn{1}{|c}{ Role of Internet } \\
\hline optimism & $\begin{array}{l}\text { mobilization, transformation, and participatory and } \\
\text { deliberative democracy }\end{array}$ & deterministic (positive) \\
\hline pessimism & $\begin{array}{l}\text { reinforcement, digital inequality (digital divide), } \\
\text { "engaging those already engaged" }\end{array}$ & deterministic (negative) \\
\hline skepticism & $\begin{array}{l}\text { normalization, reflection(mirroring), displacement, } \\
\text { complement, "politics as usual" }\end{array}$ & reflected and socially shaped \\
\hline
\end{tabular}

Source: Park \&Perry 2008, p. 193.

Despite the rapid rise in social media use in actual politics, there are two competing perspectives about its impact on public participation. The first perspective claims that social media have a positive impact on individuals' public participation (Park, Kee, \& Valenzuela, 2009). The second cautions that social media might be a threat rather than an opportunity because they do not necessarily empower individuals in a democratic way; instead, media distort and manipulate political discourse (Fenton \& Barassi, 2011). 
Based on quasi-experimental research using four policy-related scenarios, including the environment, health care, and airports, Frank Bridges et al. (2012) found that individual and institutional factors significantly limited social media's effect on young people's political engagement.

Despite the disagreement, scholars have raised the possibility that social media use mediates individual social behaviors, including citizen engagement and participation (Nyland, Marvez, \& Beck, 2007; Park, Kee, \& Valenzuela, 2009). Prior to the appearance of social media, social networks and interpersonal interaction were associated with political engagement, for the reason that one is likely to be motivated and affected by others who are politically active and engaged (McClurg, 2003). This likelihood persists in the digital world. Studying the relationship between Facebook users' gratifications and political and civic participation, Park and his colleagues (2009) reported that using the site to seek information is directly associated with civic and public participation, whereas other gratifications, such as socialization, entertainment, and self-status seeking, are not closely related to such participation. Park et al.'s study does not argue that Facebook necessarily facilitates civic and public participation, but it does imply that the motivation behind social media use is significant, given that those who use social media to seek information tend to be more politically active and participative. This phenomenon suggests the need to develop a theoretical framework to describe how social media use that is mediated by individuals' different motivations affects public participation.

The reinforcement and mobilization perspectives offer two distinct ways of understanding new media's role in public participation. These two perspectives have their own rationales, which are often supported by empirical evidence. The reinforcement perspective seems more applicable to the early stage in the diffusion of new media, when new media access is limited by high prices. The mobilization perspective, meanwhile, is likely more applicable to the later stage of diffusion, when the accessibility and affordability of new media improves. The reinforcement perspective tends to emphasize new media's supplementary effect, which refers to the possibility that new media offer additional political information sources and an additional public sphere for political involvement (Vitak et al., 2011; Wellman et al., 2001). The mobilization perspective is better suited to social media because social media are more accessible and affordable than other media. The mobilization view seems especially applicable to the young, who are widely engaged in social media activities.

Related to the contrasting reinforcement and mobilization perspectives is the question of whether social media use complements political activism or replaces it. The complementation effect posits that the time an individual spends on new media enhances his or her political interest and participation. The substitution effect, however, 
views the time an individual spends on social media as detracting from his or her political interest and participation. An individual may be subject to different effects depending on his or her political interest level and on what motivates hi or her social media use. One study suggested that social media use is positively associated with civic engagement but is not necessarily linked to public participation (Zhang, Johnson, Seltzer, et al., 2010). As summarized, the effect of social media use on public participation is thus not clearly identified.

\section{Social Media Use Motivation and Public Participation Understood through the Lens of Expectancy Theory}

One of the most powerful motivation theories is expectancy theory. Classic expectancy theory (Vroom, 1964) posits that an individual behaves in a particular way based on his or her motivation for selecting that particular behavior instead of other behaviors, given the expected results of the selected behavior. The key element of expectancy theory is that outcome desirability affects an individual's behavioral choices. It attempts to understand the degree of motivational force as a function of expectancy, instrumentality, and valance. Essentially, expectancy refers to an individual's belief that his or her effort will lead to the attainment of the first level of desired goals. Expectancy is closely associated with individuals' previous experience and efficacy. Individual motivation is also affected by instrumentality, which refers to the probability that achieving the first goal level will enable one to achieve the ultimate or second desired goal level. Valence is often defined as the degree to which an individual values the importance of desired or specific outcomes.

It is possible to use classic expectancy theory to develop a theoretical framework that accounts for the impact of social media use on individuals' public participation. For example, an individual's belief that his or her actions can affect politics represents that individual's degree of political efficacy, and those who have strong political efficacy are more likely to be politically engaged. The literature suggests that there are two different political efficacy types: internal and external. Internal political efficacy refers to an individual's belief in his or her political understanding and participation, while external political efficacy refers to an individual's belief in the effectiveness of his or her participation in influencing politics. Arguably, internal political efficacy is analogous to the first expectation level because a person who has a higher internal efficacy level is more likely to understand the nature of political affairs and to believe that he or she can perform well in politics. External efficacy is similar to the second expectation level (i.e., instrumentality) in the context of public participation because external efficacy basically indicates the extent to which an individual's public participation changes and 
influences politics. In other words, a person who has a higher external efficacy level is more likely to believe that his or her public participation has external effects. Based on the valence concept in expectancy theory, we define the valence of social media use in politics as the extent to which an individual values social media as a tool for obtaining political information and facilitating public participation. ${ }^{4}$ Drawing on expectancy theory, we can understand Public participation understood as a function of internal efficacy, external efficacy, and the valence of social media in politics. Thus, we posit a positive association between public participation with internal efficacy, external efficacy, and perceived political importance of social media (the valence of social media in politics).

\section{The Nature of Social Media: Facebook and Twitter}

Despite their similarities in connecting individuals, there are differences between Facebook and Twitter with respect to connectivity, content, communication, and purposes. Facebook is often considered more convenient than Twitter for connecting those who already have established relationships and promoting interaction among them. On the other hand, although Twitter has a 140-character limit on the message length, the communication mode is more interactive and open because users can follow other users without their approval and receive updates without having to login. For these reasons, Facebook is more popular among those who connect to maintain a strong-tie network, while Twitter is more popular among those who want to share information and communicate with others in a weak-tie network. In other words, Facebook is more likely to be used widely among friends, families, and colleagues to share personal information and interests. Likewise, it might be used to share political views and perspectives among those within a strong-tie network. With its more open characteristics, Twitter is often used by popular politicians to disseminate specific information or political messages to followers as well as to nonfollowers via retweeting or traditional media coverage. In this regard, Twitter's information multiplier effect is larger and more instant than that of Facebook. Similar to the fiscal multiplier effect, the information multiplier effect refers to the extent to which information supply increases in response to information network changes.

4. It should be noted that the concept of the valence of social media use in politics is somewhat different from the original concept of valence in expectancy theory, where valence refers to the extent to which a person values desired outcomes. The valence of social media in politics reflects the extent to which individuals value the use of social media in politics but not necessarily political participation. 
Likewise, just as the fiscal multiplier effect differs among countries depending on each country's economy and fiscal policies, Twitter and Facebook's information multiplier effects can vary among countries. For example, proportionally speaking, more people use Facebook and Twitter in the United States than in Korea, but Twitter's information multiplier effect is perhaps greater in Korea because politicians' Twitter messages are widely retweeted and covered by traditional media in Korea. This variation in the volume and nature of social media usage and communication may be closely associated with the manner in which social media affect public participation. This association leads us to hypothesize that Twitter and Facebook use effects are likely to vary, reflecting the unique nature of social media use and unique characteristics of different social media types in each country.

\section{Interaction between Social Media Use and the Valence of Social Media in Politics}

People use social media for multiple purposes, from maintaining personal and social relationships to entertainment and political activities. Although a direct relationship between social media use and public participation is likely to exist, the effect of social media use on public participation is no doubt moderated by an individual's motivating factors. For example, those who consider social media to be an important communication tool with which to search and share political information with others are likely to use social media differently from those who do not place a high value on the role of social media in politics. The perceived importance of social media in politics is an important motivational factor that represents the degree to which individuals are inclined to use social media for political purposes versus other purposes. The impact of social media use on public participation is likely to be much greater among those who attach a high political valence to the use of social media. In line with studies that have examined the moderating effect of media use and political interest (Kwak, 1999), we propose that the political importance of social media (the valence of social media in politics) moderates the effect of social media use on public participation.

\section{DATA COLLECTION AND MEASURES}

\section{Survey Procedures and Samples}

Samples of 525 Americans enrolled at a large midwestern university in the United States and 486 Korean college students enrolled at two different universities in Seoul and a metropolitan area in Korea $(\mathrm{N}=1,011)$ were used for the empirical analysis of 
this study. I recruited undergraduate students from various classes on a voluntary basis to participate in the study and assured them that their responses would be confidential. Students who participated in the survey were given extra credit by their instructors, and those who decided not to participate in the survey were given the option to complete alternative assignments for the same amount of extra credit. Paper-based survey questionnaires were developed initially in English, translated into Korean, and then translated back into English to ensure that the content of two surveys administered in the two different countries was comparable. The survey was administered three weeks prior to the presidential elections in each country. Students were given 20 minutes to complete the survey.

American respondent ages ranged from 18 to 25, with an average age of 20, and Korean respondents' ages ranged from 18 to 28, with an average age of 22.Of American students surveyed, $51.6 \%$ were male and $48.4 \%$ female, while $44.4 \%$ of the Korean students were male and $55.6 \%$ female. Over $85 \%$ of the American students were white/ non-Hispanic ( $\mathrm{N}=448), 5.9 \%$ were American Indian/Alaskan Native/non-Hispanic $(\mathrm{N}=31), 4.4 \%$ were Asian American $(\mathrm{N}=23), 3.0 \%$ were Hispanic/Latino $(\mathrm{N}=16)$, and $0.4 \%$ were other $(\mathrm{N}=2)$. The Korean sample was ethnically homogenous.

\section{MEASURES}

Two public participation types were measured in this study: offline public participation and online public participation.

\section{Online Public Participation}

Online political participation was conceptualized in terms of any online political activity. Six questions were measured on a four-point scale-(1) never, (2) sometimes, (3) often, (4) very often - and added into a single index. The Cronbach's $\alpha$ for the U.S. and Korean samples were 0.72 and 0.70 , respectively. The questions were as follows: "How often have you visited municipality websites in the last 12 months?," "How often have you visited government and public administration websites in the last 12 months?," "How often have you visited websites with political content in the last 12 months?," "How often have you reacted online to an Internet message or article in the last 12 months?," "How often have you signed online petitions in the last 12 months?," and "How often have you participated in online polls in the last 12 months?" 


\section{Offline Public Participation}

Offline public participation was gauged by asking respondents how often (on a fourpoint scale from never to very often) they participated in political activities. Cronbach's $\alpha$ for the U.S. and Korean samples was 0.73 and 0.77 , respectively. The questions were as follows: "How often have you worked or volunteered for political groups or candidates?," "How often have you tried to persuade others in an election in the last 12 months?, "'How often have you signed a petition in the last 12 months?," "How often have you worked or displayed a badge or sticker related to a political or social cause in the last 12 months?," and "How often have you deliberately bought certain products for political, ethical, or environmental reasons in the last 12 months?"

\section{News Use}

To assess the media and media content types that respondents usually consumed, a set of detailed questions was asked. For this study, only news use was considered. Respondents were asked how much time they spent on newspapers, TV news, radio news, and Internet news on an average weekday (none, 1-5 minutes, 6-10 minutes, 11-15 minutes, 16-30 minutes, 31-60 minutes, 61-90 minutes, more than 90 minutes).

Social media use was measured through two social media sites, Facebook and Twitter. However, the study did not combine the two measures to create a social media use index; instead, the two measures were used separately because the study aimed to examine the differential effect of two different social media sites.

\section{Facebook Use}

Facebook use was determined by multiplying the number of days a week by the amount of time per day. The following questions were asked: "In a typical week, about many days do you visit Facebook?" and "On a typical day, about how much time do you spend on Facebook?"'

\section{Twitter Use}

Twitter use was also determined by multiplying the following two items: "In a typical week, about how many times do you use Twitter?" and "On a typical day, how many times do you tweet?" 


\section{Political Efficacy}

There are two types of political efficacy: internal and external. Internal political efficacy was measured by responses to the following four statements using a 10-point Likert-type scale (i.e., strongly disagree to strongly agree): "Sometimes politics and government seem so complicated that a person like me can't really understand what's going on (reversed)"; "I consider myself well qualified to participate in politics"; "I feel that I could do as good a job in public office as most other people"; and "I feel that I am better informed about politics than most people." These items were summed into an additive index, in which a higher number indicated a higher degree of political efficacy. The Cronbach's $\alpha$ for the United States and Korean samples was 0.79 and 0.75 , respectively.

External political efficacy was measured by responses to the following four statements using a 10-point Likert-type scale: "Voting gives people an effective way to influence what the government does"; "I can make a difference if I participate in the election process"; "My vote makes a difference"; and "I have a real say in what the government does." These items were summed into an additive index. Cronbach's $\alpha$ for the U.S. and Korean samples was 0.88 and .90 , respectively.

\section{Social Media's Political Importance}

The variable for the perceived political importance of social media use was created by including four items (reversed) using a four-point scale: (1) regularly, (2) somewhat important, (3) not too important, (4) not at all important (Cronbach's $\alpha=.81$ for the United States and.92 for Korea). The following questions were asked: "How important are social network sites when it comes to finding other people who share your views about important political issues?," "How important are social networking sites when it comes to recruiting people to get involved with political issues that matter to you?," "How important are social networking sites when it comes to keeping up with political news?," and "How important are social networking sites when it comes to debating or discussing political issues with others?"

\section{Control Variables}

Several variables related to public participation were included in the analysis to control for potential confounding factors. Respondent age and gender data were collected. In addition, respondents were asked to rate their political ideology using a five-point Likert-scale that ranged from strongly conservative to strongly liberal, and then these 
Table 3. Descriptive Statistics

\begin{tabular}{|c|c|c|c|c|c|c|}
\hline Variables & Means & (US) & $\mathrm{N}$ & Means 8 & (Korea) & $\mathrm{N}$ \\
\hline age & 20.17 & 1.37 & 525 & 22.15 & 2.38 & 486 \\
\hline sex & 1.48 & 0.50 & 525 & 1.55 & .50 & 486 \\
\hline political ideology & 1.72 & 0.62 & 487 & 1.99 & .59 & 415 \\
\hline TV news use & 2.81 & 2.19 & 525 & 2.36 & 1.88 & 486 \\
\hline newspaper use & 1.40 & 1.59 & 525 & 1.11 & 1.73 & 486 \\
\hline Radio news use & 1.08 & 1.75 & 525 & 0.52 & 1.24 & 486 \\
\hline Internet news use & 4.04 & 2.21 & 525 & 3.51 & 1.53 & 486 \\
\hline Facebook use & 21.81 & 11.85 & 525 & 13.61 & 11.63 & 471 \\
\hline Twitter use & 10.30 & 27.89 & 525 & 1.66 & 5.10 & 479 \\
\hline $\begin{array}{l}\text { Political importance } \\
\text { of social media use }\end{array}$ & 8.40 & 3.02 & 513 & 9.24 & 3.28 & 471 \\
\hline
\end{tabular}

responses were divided into three categories according to their ideological strength. More descriptive statistics are provided in table 3.

\section{RESULTS}

To test the proposed hypotheses and examine the moderating effect of social media's perceived significance in politics, I carried out hierarchical regression analyses with SPSS 18.0. Several two-way interaction terms were constructed. To reduce potential multicollinearity problems, I employed mean-centered interaction variables, constructing each interaction variable by subtracting each variable's mean value from the original score. Table 4 shows the results of two hierarchical regression analyses in predicting offline and online public participation.

In predicting offline public participation, the control block accounted for $8.8 \%$ (United States.) and $1.7 \%$ (Korea) of the dependent variable's total variance, with ideological strength making the greatest contribution $(\beta=.19, p<.001)$ in the U.S. model and age being the most significant $(\beta=-.10, p<.05)$ in the Korean model. In the second block, media use variables accounted for only 3.8\% (United States) and 2.7\% (Korea) of offline public participation. Only radio news use was significant $(\beta=.10, p<.05)$ in the U.S. model, while only newspaper use was significant $(\beta=.08, p<.05)$ in the Korean model. In the third block, social media use accounted for $2.3 \%$ (United States) and 
Table 4. Predicting Offline and Online Public Participation in the United States and Korea

\begin{tabular}{|c|c|c|c|c|}
\hline & \multicolumn{2}{|c|}{ Offline Public Participation } & \multicolumn{2}{|c|}{ Online Public Participation } \\
\hline & United States & Korea & United States & Korea \\
\hline \multicolumn{5}{|l|}{ Control Variables } \\
\hline age & $.02(.08)$ & $-.10(.04)^{*}$ & $.01(.10)$ & $-.01(.06)$ \\
\hline sex & $.05(.22)$ & $-.05(.18)$ & $.11(.30)^{*}$ & $-.03(.26)$ \\
\hline strength of political ideology & $.19(.17)^{\star \star \star}$ & $-.02(.15)$ & $.11(.22)^{*}$ & $-.07(.22)$ \\
\hline Incremental R² (\%) & $8.8 \%$ *** & $1.7 \%(\mathrm{~ns})$ & $6.3 \% \%^{* * *}$ & $4.0 \%(\mathrm{~ns})$ \\
\hline \multicolumn{5}{|l|}{ Media Use } \\
\hline TV news use & $-.08(.06)$ & $-.06(.06)$ & $-.03(.07)$ & $.04(.08)$ \\
\hline newspaper use & $-.01(.07)$ & $-.08(.05)^{*}$ & $-.06(.09)^{*}$ & $.03(.07)$ \\
\hline radio news use & $-.10(.07)^{\star}$ & $-.01(.08)$ & $-.02(.08)$ & $.08(.11)$ \\
\hline Internet news use & $-.05(.06)$ & $-.02(.08)$ & $-.12(.08)^{*}$ & $.16(.09)^{\star \star}$ \\
\hline Incremental R² (\%) & $3.8 \%$ ** & $2.7 \% *$ & $5.5 \% \%^{* \star \star}$ & $8.2 \%{ }^{* * *}$ \\
\hline
\end{tabular}

Social Media Use

\begin{tabular}{l|c|c|c|c}
\hline Facebook use & $-.11(.01)^{\star \star}$ & $-.03(.01)$ & $.09(.01)^{\star}$ & $.01(.01)$ \\
\hline Twitter use & $-.01(.01)$ & $-.22(.02)^{\star \star \star}$ & $.01(.02)$ & $.20(.03)^{\star \star \star}$ \\
\hline Incremental $\mathrm{R}^{2}(\%)$ & $2.3 \%^{\star \star}$ & $13.9 \%^{\star \star \star}$ & $2.0 \%^{\star}$ & $9.9 \%^{\star \star \star}$ \\
\hline
\end{tabular}

\section{Motivational Variables}

\begin{tabular}{|c|c|c|c|c|}
\hline social media use's political importance & $.25(.04)^{\star \star \star}$ & $.31(.04)^{\star * *}$ & $.19(.05)^{\star \star \star}$ & $.14(.05)^{*}$ \\
\hline internal political efficacy & $.28(.02)^{\star \star \star}$ & $.25(.02)^{\star \star \star}$ & $.32(.02)^{\star * *}$ & $.17(.02)^{\star \star}$ \\
\hline external political efficacy & $.08(.01)$ & $.08(.01)$ & $.04(.02)$ & $.16 \quad .02)^{\star \star}$ \\
\hline Incremental $\mathrm{R}^{2}(\%)$ & $16.4 \%$ *** & $20.1 \%$ *** & $14.4 \%$ *** & $10.9 \%$ *** \\
\hline $\mathrm{N}$ & 461 & 381 & 386 & 381 \\
\hline Total Adj. R (\%) & $30 \% * * *$ & $36 \% * * *$ & $27 \% * * *$ & $26 \%$ *** \\
\hline Total R R $\left.^{2} \%\right)$ & $31 \% \%^{* \star *}$ & $38 \% * * *$ & $29 \% * * *$ & $28 \%$ *** \\
\hline
\end{tabular}

Note: Betas refer to standardized regression coefficients prior to entry. ${ }^{*} \mathrm{p}<.05,{ }^{* *} \mathrm{p}<.01,{ }^{* * *} \mathrm{p}<.001$.

$13.9 \%$ (Korea). Facebook use was significant $(\beta=.11, p<.01)$ in the U.S. model, and Twitter use was significant $(\beta=.22, p<.001)$ in the Korean model. Motivational variables (i.e., the political importance of social media use, internal political efficacy, and external political efficacy) were entered in the last block. This block accounted for $16.4 \%$ (United States) and $20.1 \%$ (Korea) in predicting offline public participation. The political 
importance of social media use $(\beta=.25, p<.001)$ and internal political efficacy $(\beta=.28$, $p<.001)$ in this block were statistically significant in the U.S. model, while the political importance of social media use $(\beta=.31, p<.001)$ and internal political efficacy $(\beta=.25$, $p<.001)$ were significant in the Korean model.

To test any moderation effects of Facebook or Twitter use's political importance on the two public participation types, several hierarchical regression analyses were run (table 3). In the U.S. model, social media use significantly accounted for offline public participation $\left(R^{2}=2.3 \%, \mathrm{p}<.01\right)$, but only Facebook use was significant $(\beta=.12, p<.01)$ after control and media use variables were controlled for. The political importance of social media use was also significant $(\beta=.30, p<.001)$. In addition, the interaction term between Facebook use and the political importance of social media was significant and positive $(\beta=.14, p<.01)$, which indicates that those who use Facebook more and who consider social media as more politically important were more likely to participate in offline public political activities than those who use Facebook to a lesser degree and who regard social media as less politically important. However, no interaction effects between the two independent variables were found to predict online public participation in either the U.S. or the Korean model.

Social media use was also significant in the Korean model, and it likewise contributed to offline public participation $\left(R^{2}=13.9 \%, p<.001\right)$, with Twitter use being significant ( $\beta=.22, p<.001)$ after control and media use variables were controlled for. The political importance of social media use was also significant $(\beta=.31, p<.001)$. In addition, the interaction term between Twitter use and the political importance of social media use was significant and positive $(\beta=.12, p<.01)$, which indicates that those who use Twitter more and who consider social media as more politically important were more likely to be involved in offline public participation than those who use Twitter to a lesser degree and who regard social media as less politically important.

The following equations were used to illustrate the significant two-way interaction effects in table 3's regression model:

1. offline public participation (United States) $=.61+(.23)$ ideological strength $+(.11)$ radio news $+(.12)$ Facebook use $+(.30)$ the political importance of social media use $+(.14)$ Facebook use $X$ the political importance of social media use (figure 1)

2. offline public participation (Korea) $=9.15+(-.10)$ age $+(.09)$ newspaper use $+(.22)$ Twitter use $+(.31)$ the political importance of social media use + (.12) Twitter use $\mathrm{X}$ the political importance of social media use (figure 2)

These figures were obtained from table 5. To produce figure 1, I first broke the equation into two Facebook use groups (high and low). I arbitrarily assigned a score of 
Table 5. Predicting Offline and Online Public Participation in the U.S. and Korea (with the Moderating Effect of the Political Importance of Social Media)

\begin{tabular}{|c|c|c|c|c|}
\hline & \multicolumn{2}{|c|}{ Offline Public Participation } & \multicolumn{2}{|c|}{ Online Public Participation } \\
\hline & United States & Korea & United States & Korea \\
\hline \multicolumn{5}{|l|}{ Control Variables } \\
\hline age & $.07(.08)$ & $-.10(.04)^{\star}$ & $.01(.10)$ & $-.02(.06)$ \\
\hline sex & $.01(.23)$ & $-.05(.18)$ & $.11(.30)^{*}$ & $-.02(.27)$ \\
\hline strength of political ideology & $.23(.18)^{\star \star \star}$ & $-.02(.15)$ & $.11(.22)^{*}$ & $-.04(.22)$ \\
\hline Incremental R² (\%) & $8.8 \%{ }^{* * *}$ & $1.7 \%(\mathrm{~ns})$ & $6.7 \%$ *** & $0.4 \%(n s)$ \\
\hline \multicolumn{5}{|l|}{ Media Use } \\
\hline TV news use & $-.04(.07)$ & $-.06(.06)$ & $-.03(.07)$ & $-.08(.08)$ \\
\hline newspaper use & $-.06(.06)$ & $-.09(.05)^{\star}$ & $-.06(.09)^{\star}$ & $-.02(.07)$ \\
\hline radio news use & $-.11(.07)^{\star}$ & $-.01(.08)$ & $-.02(.08)$ & $-.08(.11)$ \\
\hline Internet news use & $-.02(.06)$ & $-.02(.08)$ & $-.12(.08)^{\star}$ & $-.21(.09)^{\star \star}$ \\
\hline Incremental R (\%) & $3.8 \% \%^{* *}$ & $2.7 \%^{*}$ & $5.7 \%$ *** & $8.3 \%^{* * *}$ \\
\hline \multicolumn{5}{|l|}{ Social Media Use } \\
\hline Facebook use & $-.12(.01)^{\star \star}$ & $-.03(.01)$ & $-.09(.01)^{\star}$ & $-.02(.01)$ \\
\hline Twitter use & $-.01(.01)$ & $-.22(.02)^{\star * \star}$ & $-.01(.02)$ & $-.24(.03)^{\star \star \star}$ \\
\hline Incremental R² (\%) & $-2.3 \%$ ** & $13.9 \%$ *** & $2.1 \%{ }^{*}$ & $9.9 \%$ *** \\
\hline \multicolumn{5}{|l|}{ Motivational Variables } \\
\hline political importance of social media use & $-.30(.04)^{\star \star \star}$ & $-.31(.04)^{\star \star \star}$ & $-.19(.05)^{\star * \star}$ & $-.26(.05)^{\star \star \star}$ \\
\hline Incremental R² (\%) & $8.1 \%{ }^{* * *}$ & $13.2 \%{ }^{* * *}$ & $5.5 \%$ *** & $5.4 \%$ *** \\
\hline \multicolumn{5}{|l|}{ Interaction Terms 5} \\
\hline $\begin{array}{l}\text { Facebook use } \times \text { political importance } \\
\text { of social media use }\end{array}$ & $-.14(.01)^{\star \star}$ & $-.08(.01)$ & $0.1(0.1)$ & $-.05(.01)$ \\
\hline $\begin{array}{l}\text { Twitter use } \times \text { political importance of } \\
\text { social media use }\end{array}$ & $-.05(.01)$ & $-.12(.01)^{\star \star}$ & $0.1(0.1)$ & $-.01(.01)$ \\
\hline Incremental R² (\%) & $1.1 \%{ }^{*}$ & $2.5 \%{ }^{* *}$ & $0.0 \%$ & $.02 \%$ (ns) \\
\hline $\mathrm{N}$ & 463 & 384 & 386 & 385 \\
\hline Total Adj. R² (\%) & $22 \%$ *** & $31 \% * * *$ & $19 \% * * *$ & $22 \%$ *** \\
\hline Total R² (\%) & $24 \%^{* * *}$ & $33 \%$ *** & $20 \%$ *** & $24 \%^{* * *}$ \\
\hline
\end{tabular}

Note: Interaction variables were mean-centered prior to entries.

${ }^{\star} \mathrm{p}<.05,{ }^{* *} \mathrm{p}<.01,{ }^{* * *} \mathrm{p}<.001$. 
0 to the low Facebook use group and 1 to the high Facebook use group, assigning mean values to the other variables, except for the political importance of social media use. Next, I divided the political importance of social media into two groups, giving a mean value of -1 standard deviation to the group with low political importance of social media use and a mean value of +1 standard deviation to the group with high political importance of social media use.

To produce figure 2, I broke the equation into two Twitter use groups (high and low) by arbitrarily assigning a score of 0 to the low Twitter use group and 1 to the high Twitter use group; I gave mean values for other variables, excluding the political importance of social media. Then, I followed the same aforementioned procedure to identify two groups with respect to the political importance of social media use.

Figure 1. Interaction Terms between Facebook Use and Offline Public Participation Motivation (United States)

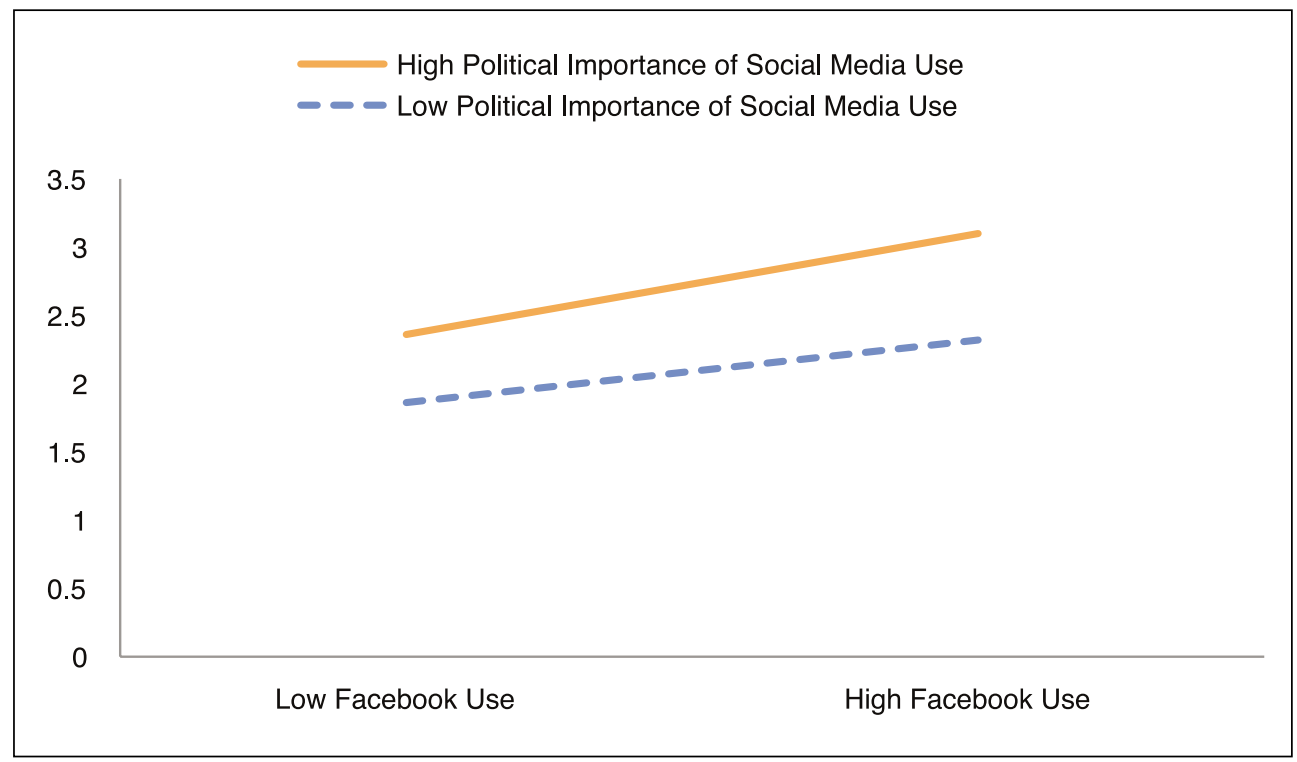

Figure 1 shows that those reporting high Facebook use and high motivation scored higher in public participation than in other categories. However, no interaction effects between the two independent variables were found to predict online public participation.

5. I performed an interaction analysis on the political efficacy variables and social media use, but I eliminated the interaction terms because no interaction effects were found between the variables. 
Figure 2. Interaction Terms between Twitter Use and Offline Public Participation Motivation (Korea)

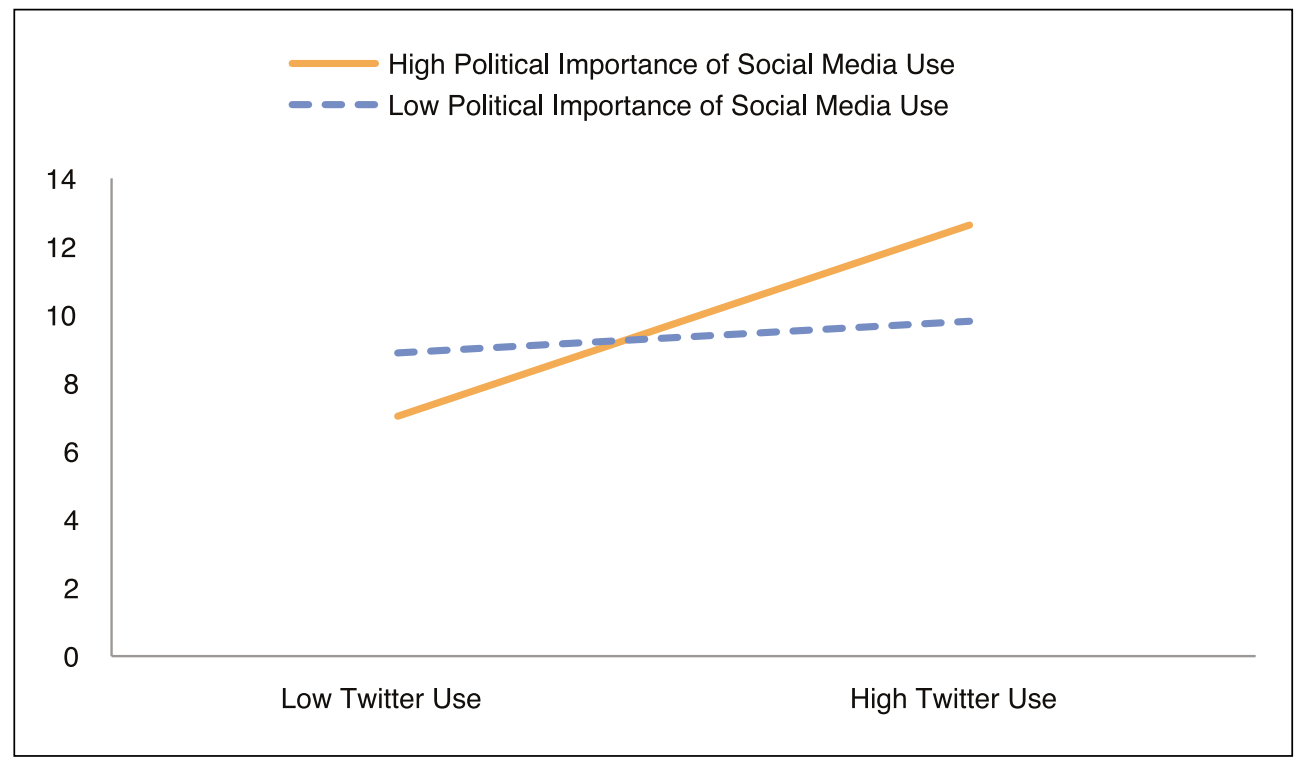

Figure 2 shows that those reporting high Twitter use and claiming a high political importance for social media use scored higher in public participation than in other categories.

\section{CONCLUSIONS}

This empirical study shows that the impact of social media use on the young's public participation is statistically significant and positive both in the United States and Korea, or at least that it was during the intense presidential election campaigns in 2012. The results provide an important contribution to the ongoing debate regarding whether young people's increased social media use positively affects public participation or disengages them from politics.

However, the empirical results show a sharp contrast between the two countries. This study found that Facebook use is much more influential for young people's public participation in the United States, while Twitter use has a greater impact on young people's public participation in Korea. This finding is partly explained by cultural differences in political communication. The sharing of political views and information in the United States in contrast to Korea is more likely to occur among people within 
strong-tie networks than those within weak-tie networks because many Americans feel uncomfortable in sharing political views with those who are not sufficiently close or have different political views. This pattern is particularly prevalent in the United States because conversations on politics, like those concerning religion, are often perceived as divisive, grounded in positions that are difficult to reconcile (Eliasoph, 1998; Studson, 1997). Generally, young Koreans seem to be more active than American college students in sharing political information and perspectives within weak-tie networks such as Twitter. In particular, those who are highly motivated are more likely to seek out political opinions and discussion than hard knowledge from sources such as political leaders (Lee and Oh, 2013), which might eventually stimulate political interest and lead to a higher level of public participation. This study also suggests that Twitter's information multiplier effect is much greater than that of Facebook in Korea, in contrast to the pattern observed in the United States, because traditional media, such as newspapers and television, frequently use Twitter as an important source of political news, particularly when politicians engage in Twitter exchanges regarding politically salient issues. A recent study (Choi \& Park, 2014) confirms that Twitter is often strategically used by politicians and political organizers to mobilize support and strengthen solidarity. This finding suggests that the impact of Twitter on political activism in Korea has been greater than in the United States, an effect that was magnified after the introduction of "Twitaddons.com," a Twitter-based application service, in March 2010, which allows Twitter users to organize online groups and to post and retweet particular messages of interest.

As in previous studies, individual motivation was found to be an important factor in both offline and online public participation. The political motivational factor was found to be critical in driving public participation among young people. Both American and Korean young adults who value the role of social media in politics appear likely to have a higher level of offline public participation than those do not. Interestingly, the political valence of social media does not appear to significantly moderate the effect of social media use on online public participation, most likely because online public participation requires less engagement or commitment than offline public participation and thus does not significantly affect social media use beyond the specific use of social media for public participation. In contrast, the political valence of social media appears to escalate the effect of social media on offline public participation, which often requires a higher level of motivation and interest than online public participation.

This study also confirms that the motivational factors determining public participation have a strong moderating effect. This effect appears to vary in different political cultures due to differing interactions between motivational factors and social media use. This finding suggests that the impact of social media use is not necessarily equal 
across societies but rather dependent on the ways in which different societies use different social media channels. Overall, this study offers the perspective that social media are alternative media that can facilitate young people's public participation and that such participation is likely to be promoted and moderated by individual valence and perceptions about social media's political significance. In other words, both alternative technologies and individual characteristics are significant in influencing young people's public participation. To improve their communication and interaction with young people, politicians and policy makers also must pay closer attention to the variation in the impact of different social media channels on public participation.

There are limitations in this study. Its use of the technique of convenience sampling of college students, for example, is a weakness owing to the self-selected nature of the sampling method. Further, these findings are not necessarily generalizable to other countries because the samples were drawn from a limited number of college students from two countries. The study suggests that future research consider more social media channels to better understand the impact of social media on public participation.

\section{REFERENCES}

Andolina, Jenkins, Faison, \& Flanagan. 2001.

Andolina, M. W., Jenkins, K., Zukin, C., \& Keeter, S. 2003. Habits from the home lessons from school: Influences of youth civic engagement. Political Science and Politics, 36(2): 275-280.

Arno, C. 2012. Mapping social media trends around the world: Social media today. Retrieved on March 16, 2012, from http://socialmediatoday.com/christian-arno/ 470898/mapping-social-media-trends-around-world.

Bakker, T. P., \& de Vreese, C. H. 2011. Good news for the future? Young people, Internet use, and political participation. Communication Research, 38(4): 451470.

Bridges, F., Appel, L., \& Grossklags, J. 2012. Young adults' online participation behaviors: An exploratory study of Web 2.0 use for political engagement. Information Policy, 17(2): 163-176.

Castells, M. 2009. Communication power. Oxford: Oxford University Press.

Calenda, D., \& Meijer, A. 2009. Young people, the Internet and political participation: Findings of a Web survey in Italy, Spain and the Netherlands. Information, Communication, and Society, 12(6): 879-898.

Choi, S., \& Park, H. W. 2014. An exploratory approach to a Twitter-based community centered on a political goal in South Korea: Who organized it, what they 
shared, and how they acted. New Media and Society, 16(1): 129-148.

Conway, M. M. 2000. Political participation in the United States (3rd ed.). Washington, DC: CQ Press.

Cummings, J. N., Butler, B., \& Kraut, R. 2002. The quality of online social relationships. Communications of the ACM, 45(7): 103-108.

Delli Carpini, M. X., \& Keeter, S. 2003. The Internet and an informed citizenry. In M. Cornfield \& D. M. Anderson (eds.), The civic web: Online politics and democratic values (pp. 129-153). Lanham, MD: Rowman and Littlefield.

Eliasoph, N. 1998. Avoiding politics: How Americans produce apathy in everyday life. Cambridge: Cambridge University Press.

Fenton, N., \& Barassi, V. 2011. Alternative media and social networking sites: The politics of individualization and political participation. Communication Review, 14(3): 179-196.

Foot, K. A., \& Schneider, S. 2006. Web campaigning. Cambridge, MA: MIT Press.

Gil de Zúñiga, H., Jung, N., \& Valenzuela, S. 2012. Social media use for news and individuals' social capital, civic engagement and political participation. Journal of Computer Mediated Communication, 17(3): 319-336.

Hoffman, L. 2012. Participation or communication? An explication of political activity in the Internet age. Journal of Information Technology and Politics, 9(3): 217-233.

Kann, M. E., Berry, J., Gant, C., \& Zager, P. 2007. The Internet and youth political participation. First Monday 12(8): http://firstmonday.org/article/view/1977/1852.

Kim, M., \& Park, H.W. 2012. Measuring Twitter-based political participation and deliberation in the South Korean context by using social network and Triple Helix indicators. Scientometrics, 90(1): 121-140.

Kim, Y., Sohn, D., \& Choi, S. M. 2011. Cultural difference in motivations for using social network sites: A comparative study of American and Korean college students. Computers in Human Behavior, 27(1): 365-372.

Kraut, R., Patterson, M., Lundmark, V., Kiesler, S., Mukopadhyay, T., \& Scherlis, W. 1998. Internet paradox: A social technology that reduces social involvement and psychological well-being? American Psychologist, 53(9): 1017-1031.

Lee, E. J., \& Oh, S. Y. 2013. Seek and you shall find? How need for orientation moderates knowledge gain from Twitter use. Journal of Communication, 63(4): 745-765.

Lee, J. K., Choi, J., Kim, C., \& Kim, Y. 2014. Social media, network heterogeneity, and opinion polarization. Journal of Communication, 64(4): 702-722.

McClurg, S. D. 2003. Social networks and political participation: The role of social interaction in explaining political participation. Political Research Quarterly, 56(4): 448-464.

Metzgar, E., \& Maruggi, A. 2009. Social media and the 2008 US presidential election. 
San Jose, CA: Society for New Communication Research.

Michelsen, E., Zaff, J. F., \& Hair, E. C. 2002. Civic engagement programs and youth development: A synthesis. Washington, DC: Child Trends.

Mindich, D. T. Z. 2005. Tuned out: Why Americans under 40 don't follow the news. New York: Oxford University Press.

Nie, N. H. 2001. Sociability, interpersonal relations, and the Internet: Reconciling conflicting findings. American Behavioral Scientist, 45(3): 420-35.

Nyland, R., Marvez, R., \& Beck, J. 2007. MySpace: Social networking or social isolation? Paper presented at the Midwinter Conference of the Association for Education in Journalism and Mass Communication, Reno, NV.

Park, H. M., \& Perry, J. 2008. Do campaign web sites really matter in electoral civic engagement? Empirical evidence from the 2004 post-election Internet tracking survey. Social Science Computer Review, 26(2): 190-212.

Park, N., Kee, K \& Valenzuela, S. 2009. Being immersed in social networking environment: Facebook groups, uses and gratifications, and social outcomes. Cyberpsychology and Behavior, 12(6): 729-733.

Putnam, R. D. 2000. Bowling alone. New York: Simon and Schuster.

Oh, Y. M., \& Park, J. 2013. The effect of political institutions on the use of citizen participation programs. Korean Journal of Policy Studies, 28(2): 25-48.

Shah, D. V., Kwak, N., \& Holbert, L. R. 2001. "Connecting" and "disconnecting" with civic life: Patterns of Internet use and the production of social capital. Political Communication, 18: 141-162.

Schudson, M. 1997. Why conversation is not the soul of democracy. Critical Studies in Mass Communication, 14(4): 297-309.

Studson. 1997.

Tolbert, C. J., \& McNeal, R. S. 2003. Unraveling the effects of the Internet on political participation? Political Research Quarterly, 56(2): 175-185.

Tumasjan, A., Sprenger, T. O., Sandner, P. G., \& Welpe, I. M. 2010. Predicting elections with Twitter: What 140 characters reveal about political sentiment. ICWSM, 10: 178-185.

Verba, S., Schlozman, K. L., \& Brady, H. E. 1995. Voice and equality: Civic voluntarism in American politics. Cambridge, MA: Harvard University Press.

Vitak, J. V., Zube, P., Smock, A., Carr, C., Ellison, N., \& Lampe, C. 2011. It's complicated: Facebook users' political participation in the 2008 election. Cyberpsychology, Behavior, and Social Networks, 14(3): 107-114.

Vroom, V. H. 1964. Work and motivation. San Francisco: Jossey-Bass.

Westling, M. 2007. Expanding the public sphere: The impact of Facebook on political communication. Retrieved on March 9, 2013, from http://www. thenewvernacular. 
com/projects/facebook_and_political_communication.pdf.

Woo, J. K., \& Kim, M. G. 2009. News media use, citizen communication, and civic participation: A communication mediation model. Korean Journal of Policy Studies, 24(2): 47-68.

Wortham, J. 2012a. Campaigns use social media to lure young voters. New York Times, October 8, B1.

Wortham, J. 2012b. The presidential campaign on social media. Retrieved on March 6, 2013, from www.nytimes.com/interactive/2012/10/08/technology/campaign-social -media.html?_r=0.

Wellman B., Hasse, A. Q. J., Witte, J., \& Hampton, K. 2001. Does the Internet increase, decrease, or supplement social capital? American Behavioral Scientist, 45(3): 436-55.

Zhang, W., Johnson, T. J., \& Seltzer, T., \& Bichard, S. L. 2010. The revolution will be networked: The influence of social networking sites on political attitudes and behaviors. Social Science Computer Review, 28(1): 75-92. 